\title{
Hotel Employees' Voice Behavior: The Role of Paternalistic Leadership and Organizational Identification
}

\author{
Wen-Long Zhuang ${ }^{1, *}$, Chun-Han Lee ${ }^{2}$ and Chung-Liang $\mathrm{Ma}^{2}$ \\ 1 Department of Culinary Arts and Hotel Management, Hungkuang University, Shalu District, \\ Taichung City 43302, Taiwan \\ 2 Ph.D. Program in Strategy and Development of Emerging Industries, National Chi Nan University, Puli, \\ Nantou 54561, Taiwan; d0982771748@yahoo.com.tw (C.-H.L.); ezxxyy@gmail.com (C.-L.M.) \\ * Correspondence: abow38@yahoo.com.tw
}

Citation: Zhuang, W.-L.; Lee, C.-H. Ma, C.-L. Hotel Employees' Voice Behavior: The Role of Paternalistic Leadership and Organizational

Identification. Sustainability 2022, 14, 256. https://doi.org/10.3390/

su14010256

Academic Editors: Chih-Hsing Sam Liu and Jeou-Shyan Horng

Received: 7 December 2021

Accepted: 25 December 2021

Published: 27 December 2021

Publisher's Note: MDPI stays neutral with regard to jurisdictional claims in published maps and institutional affiliations.

Copyright: (C) 2021 by the authors. Licensee MDPI, Basel, Switzerland. This article is an open access article distributed under the terms and conditions of the Creative Commons Attribution (CC BY) license (https:/ / creativecommons.org/licenses/by/ $4.0 /)$.

\begin{abstract}
This study explores the effect of paternalistic leadership (moral leadership, benevolent leadership, and authoritarian leadership) on hotel employees' voice behavior and the moderating role of organizational identification. This study samples employees of five-star hotels in northern, central, and southern Taiwan. Purposive sampling is used to distribute 450 questionnaires: 150 in northern Taiwan, 150 in central Taiwan, and 150 in southern Taiwan. The number of valid questionnaires was 359 , and the effective questionnaire recovery rate was $79.78 \%$. The analysis results indicate that (1) supervisors' moral leadership negatively affects hotel employees' voice behavior, (2) supervisors' benevolent leadership positively affects hotel employees' voice behavior, (3) supervisors' authoritarian leadership negatively affects hotel employees' voice behavior, (4) organizational identification moderates the relationship between moral leadership and voice behavior, (5) organizational identification moderates the relationship between benevolent leadership and voice behavior, and (6) organizational identification moderates the relationship between authoritarian leadership and voice behavior. This study also proposes managerial implications based on the analysis results. This research attempts to make contributions to the literatures of hospitality and tourism.
\end{abstract}

Keywords: paternalistic leadership; organizational identification; voice behavior; tourism; hospitality

\section{Introduction}

Hiring appropriate talent is the main concern of all organizations and a method of creating a competitive advantage [1]. Hospitality organizations have gradually shifted their focus to encouraging employees to seek opportunities to improve, and numerous practitioners and researchers consider enthusiasm at work a competitive advantage that is essential to organizational success [2,3]. Frontline employees in the hotel industry encounter problems such as long working hours, heavy workloads, lack of training, and customer misbehavior [4-7]. To adjust to changes in the industry and achieve excellent performance, organizations must constantly improve their products and frontline employees must provide constructive feedback [8]. Therefore, the antecedents of hotel industry employees' voice behavior must be identified.

Friendly and amicable managers utilize a paternalistic leadership style, which positively affects subordinates [9]. Studies on hospitality have demonstrated the effects of paternalistic leadership on employees' work engagement and extra-role customer service behavior [10]. In the hospitality industry, paternalistic leadership effectively improves employees' internal service behavior which, in turn, benefits the organization [11]. However, whether paternalistic leadership affects the voice behavior of hotel employees remains to be determined. Scholars have explored paternalistic leadership in hospitality organizations [9-11], but few studies have investigated the effect of paternalistic leadership on hotel employees' voice behavior. 
The effects of paternalistic leadership on the behavior of hotel employees may be affected by situational factors. According to social identity theory, individuals are inclined to identify with groups that satisfy needs for self-esteem, belonging, control, and meaning in life $[12,13]$. If a hotel can satisfy this need among its employees, its employees may be able to strengthen their sense of identity. Therefore, organizational identification may be a situational variable that affects the relationship between paternalistic leadership and hotel employee voice behavior.

The current research in this area appears to be relatively lacking, this study explores the effect of paternalistic leadership on hotel employees' voice behavior and the moderating role of organizational identification to fill a gap in the literature on hospitality. The findings can serve as reference for the hotel industry to improve supervisors' leadership style or the working environment.

\section{Literature Review and Hypotheses}

\subsection{Voice Behavior}

Van Dyne et al. [14] defined voice behavior as challenging the status quo and offering constructive suggestions. LePine and Van Dyne [15] indicated that voice behavior represents employees' courage to solve work-related problems by voicing their concerns. Morrison [16] defined voice behavior as the free exchange of ideas, suggestions, concerns, and opinions regarding work-related problems to improve an organization or department thereof. Bashshur and Oc [17] defined voice behavior as the free formation of ideas, opinions, suggestions, or methods of communication within or outside an organization to solve problems and improve an organization, group, or individual.

Studies have indicated that voice behavior benefits workplaces and organizations [18-20]. Studies have also indicated that voice behavior has numerous antecedents, including commitment to change [21], encouragement to participate [22], moral leadership, authoritarian leadership [23], person-organization fit [1], psychological capital [24], team-member exchange [25], transformational leadership [26], regulatory foci [18], supervisor empowerment [27], and work engagement [28]. Paternalistic leadership may also be an antecedent of hotel employees' voice behavior.

\subsection{Paternalistic Leadership and Voice Behavior}

Farh and Cheng [29] defined paternalistic leadership as a combination of strong discipline, authority, and paternal kindness. Paternalistic leadership consists of three aspects: morality, benevolence, and authority. Moral leadership refers to strong personal virtues, self-discipline, and selflessness. Benevolent leadership is the individualized and holistic care provided to ensure subordinates' well-being within and outside the work environment. Authoritarianism entails control, authority, and requiring subordinates to be humble and obedient [30]. In an organizational environment, paternalism requires that employees be treated as members of a large family [31]. Paternalistic supervisors exude a fatherly attitude toward their subordinates [32]. Chen [11] investigated employees of Taiwanese hotels for international travelers and discovered that paternalistic leadership improved the quality of internal services. Tuan [10] surveyed employees and supervisors of four- and five-star hotels in Vietnam and discovered that moral leadership and benevolent leadership positively affected employee work engagement and extra-role customer service behavior and that authoritarian leadership negatively affected employees' work engagement and extra-role customer service behavior. Redmond and Sharafizad [9] investigated Australian hospitality employees and found that paternalistic leadership encouraged discretionary effort among employees.

Social information processing theory dictates that individuals' attitudes, behaviors, and values are shaped by environmental cues and by information dictating what is valuable and appropriate [33]. From the perspective of social information processing theory [33], hotel employees often perceive supervisors with a moral leadership style as selfless people 
who lead by example; thus, employees are less likely to voice opinions that differ from those of their supervisors. Accordingly, this study advances the following hypothesis:

Hypothesis 1 (H1). Supervisors' moral leadership negatively affects hotel employees' voice behavior.

According to social information processing theory [33], if supervisors have a benevolent leadership style, then employees may perceive them as kind and understanding; to express gratitude to their supervisors, employees may offer suggestions to improve the workplace. Therefore, this study proposes the following hypothesis:

Hypothesis 2 (H2). Supervisors' benevolent leadership positively affects hotel employees' voice behavior.

From the viewpoint of social information processing theory [33], if supervisors have an authoritarian leadership style, then employees may fear that voicing differing opinions would be disrespectful. On this basis, this study proposes the following hypothesis:

Hypothesis 3 (H3). Supervisors' authoritarian leadership negatively affects hotel employees' voice behavior.

\subsection{Moderating Role of Organizational Identification}

Tajfel [34] developed the concept of organizational identification by using social identity theory. Organizational identification refers to employees' perspective of their membership in an organization. Organizational identification includes individuals expanding their personal self-concept to the organization. Individuals who strongly identify with an organization define themselves by using the characteristics of the organization and act in the organization's best interests [12,35]. Organizational identification also refers to employees' degree of attachment to an organization [36]. Hotel employees with a high degree of organizational identification derive a sense of belonging from their hotel and adhere to its policies for the sake of the company. In such a case, supervisors may exhibit a strong moral and authoritarian leadership style that discourages employees from offering suggestions or challenging the status quo to avoid offending their supervisors. Employees often perceive supervisors with a benevolent leadership style as caring and unlikely to exact punishment, which enables employees to offer suggestions without worry. Employees with a low degree of organizational identification are often dissatisfied with the status quo. Supervisors with a strong moral leadership style tend to lead with their hearts. Because subordinates are inspired by their supervisors, employees under such supervisors may offer suggestions for changing the status quo and improving their workplace. In instances of disagreement between employees and their company, employees often perceive supervisors with a benevolent and authoritarian leadership style as only caring about the company, which discourages voice behavior among employees. On this basis, this study proposes the following hypotheses:

Hypothesis 4 (H4). Organizational identification moderates the relationship between moral leadership and hotel employee voice behavior.

Hypothesis $\mathbf{5}$ (H5). Organizational identification moderates the relationship between benevolent leadership and hotel employees' voice behavior.

Hypothesis 6 (H6). Organizational identification moderates the relationship between authoritarian leadership and hotel employees' voice behavior. 
Figure 1 presents the research framework based on the hypotheses.

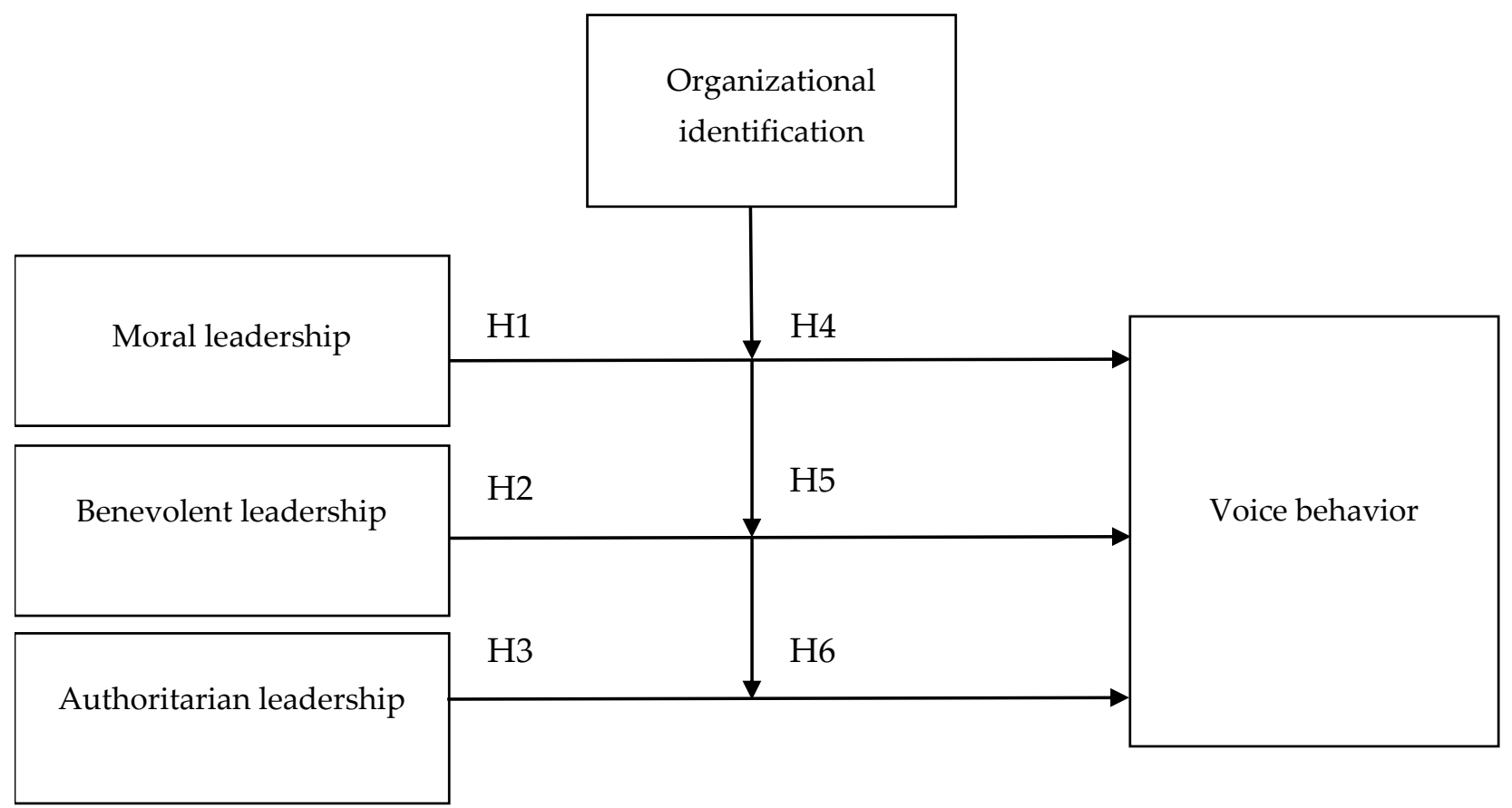

Figure 1. Conceptual framework.

\section{Methods}

\subsection{Sampling}

This study sampled employees of nine five-star hotels in northern Taiwan (three hotels), central Taiwan (three hotels), and southern Taiwan (three hotels). Purposive sampling was used to distribute questionnaires to hotels on a list of Taiwanese hotels for international travelers released by the Tourism Bureau in 2019. Hair et al. [37] indicated that to develop an effective questionnaire, the number of valid samples should be 5 to 20 times the number of items in the questionnaire. Because the questionnaire has 27 items, the effective sample size is between 135 and 540. The human resources managers of these nine five-star hotels distributed questionnaires to their employees. After the exclusion of invalid questionnaires, the number of distributed questionnaires was 450 (each hotel had 50 questionnaires to distribute).

\subsection{Measurement}

The items used in this study are three demographic variables: gender, age, and tenure. Paternalistic leadership was measured on the 15-item scale developed by Cheng et al. [38] in terms of moral leadership (five items), benevolent leadership (five items), and authoritarian leadership (five items). A sample item for assessing moral leadership is as follows: "My supervisor is responsible". A sample item for assessing benevolent leadership is as follows: "My supervisor's care for me extends to my family". A sample item for assessing authoritarian leadership is as follows: "My supervisor deliberately keeps distance between us". Organizational identification is measured using the six-item scale of Mael and Ashforth [39]. A sample item for assessing organizational identification is as follows: "When someone criticizes my company, I feel insulted". Voice behavior is measured using the six-question scale of Van Dyne and LePine [40]. A sample item for assessing voice behavior is as follows: "I offer suggestions to my supervisor to improve the workplace". 


\subsection{Statistical Analysis}

This study performed descriptive statistical, correlation, reliability, and confirmatory factor analyses of the valid questionnaire data and regression analysis of the research hypotheses by using SPSS (version 24.0) and AMOS (version 24.0; IBM, Armonk, NY, USA).

\section{Results}

\subsection{Respondent Profile}

After 8 invalid questionnaires were excluded, 367 questionnaires remained, of which 359 were valid, yielding a $79.78 \%$ return rate. Questionnaires that were incomplete or blank, had missing answers or double selection, failed to satisfy the sampling criteria, or exhibited high similarity in scores were deemed invalid. The analysis results indicate that the majority of the participants were women $(64.1 \%)$ and aged between 19 and 24 years $(53.5 \%)$. Most of the participants had 1 year or less of work experience in the hotel industry $(32.3 \%)$.

\subsection{Reliability Analysis}

A Cronbach's $\alpha$ coefficient of $>0.70$ and a revised item-total correlation of $>0.45$ were used as the measurement standards. The Crobach's $\alpha$ of moral leadership, benevolent leadership, authoritarian leadership, organizational identification, and voice behavior are $0.92,0.90,0.86,0.92$, and 0.90 , respectively. These results demonstrate that all dimensions have high reliability.

\subsection{Validity Analysis}

The confirmatory factor analysis revealed that $\chi^{2}=924.678$, degrees of freedom $=314$, root mean square error of approximation $=0.07$, incremental fit index $=0.91$, and comparative fit index $=0.91$, all indicating acceptable goodness of fit. Confirmatory factor analysis was performed to determine the validity of the scale (Table 1). A factor loading of less than 0.4 was used as the criterion to exclude items [37]. No items were deleted, and all 27 items are significant $(t>1.96, p<0.05)$. The significant factor loadings and high composite reliability indicate that the scale has convergent validity [41]. The average variance extracted (AVE) is 0.70 for moral leadership, 0.65 for benevolent leadership, 0.56 for authoritarian leadership, 0.65 for organizational identification, and 0.60 for voice behavior. Fornell and Larker [42] suggested that AVE must be greater than 0.50. If it is less than 0.50, more than $50 \%$ of the variation comes from measurement error, that is, the convergence validity is not sufficient. The AVE of each dimension is greater than 0.5, meeting the significance level and indicating acceptable convergent validity.

Table 1. Confirmatory factor analysis results.

\begin{tabular}{|c|c|c|c|c|}
\hline Items & SFL & $t$-Value & AVE & CR \\
\hline Moral leadership & & & 0.70 & 0.92 \\
\hline $\begin{array}{l}\text { Compared with leaders of other companies, my } \\
\text { supervisor has superior morals. }\end{array}$ & 0.843 & - & & \\
\hline $\begin{array}{l}\text { On the whole, I think my supervisor is morally } \\
\text { admirable. }\end{array}$ & 0.913 & 22.543 & & \\
\hline $\begin{array}{l}\text { Compared with other leaders I have met in the past, } \\
\text { my supervisor has superior morals. }\end{array}$ & 0.820 & 18.958 & & \\
\hline 1. My supervisor is responsible. & 0.810 & 18.607 & & \\
\hline 2. My supervisor is a role model. & 0.790 & 17.899 & & \\
\hline Benevolent leadership & & & 0.65 & 0.90 \\
\hline My supervisor's care for me extends to my family. & 0.782 & - & & \\
\hline My supervisor helps me solve problems in my life. & 0.856 & 17.522 & & \\
\hline My supervisor cares about my personal life. & 0.816 & 16.535 & & \\
\hline My supervisor satisfies my personal needs. & 0.783 & 15.723 & & \\
\hline My supervisor frequently asks me about my health. & 0.782 & 15.712 & & \\
\hline
\end{tabular}


Table 1. Cont.

\begin{tabular}{|c|c|c|c|c|}
\hline Items & SFL & $t$-Value & AVE & CR \\
\hline Authoritarian leadership & & & 0.56 & 0.86 \\
\hline My supervisor asks me to maintain propriety. & 0.629 & - & & \\
\hline My supervisor exhibits a sense of dignity. & 0.728 & 11.149 & & \\
\hline $\begin{array}{l}\text { My supervisor deliberately keeps distance between } \\
\text { us. }\end{array}$ & 0.794 & 11.840 & & \\
\hline $\begin{array}{l}\text { If I were to not follow my supervisor's rules, I would } \\
\text { be severely punished. }\end{array}$ & 0.799 & 11.887 & & \\
\hline $\begin{array}{l}\text { When the company's goals are not achieved, my } \\
\text { supervisor scolds me. }\end{array}$ & 0.777 & 11.668 & & \\
\hline Organizational identification & & & 0.65 & 0.92 \\
\hline When someone criticizes my company, I feel insulted. & 0.825 & - & & \\
\hline I care about what others think of my company. & 0.827 & 18.446 & & \\
\hline $\begin{array}{l}\text { I often use "we" instead of "they" to refer to my } \\
\text { company. }\end{array}$ & 0.763 & 16.428 & & \\
\hline The success of the company is a success for me. & 0.838 & 18.816 & & \\
\hline $\begin{array}{l}\text { When someone praises my company, I feel as if I have } \\
\text { been praised. }\end{array}$ & 0.811 & 17.933 & & \\
\hline $\begin{array}{l}\text { I feel embarrassed when news media circulate } \\
\text { negative rumors about my company. }\end{array}$ & 0.769 & 16.608 & & \\
\hline Voice behavior & & & 0.60 & 0.90 \\
\hline $\begin{array}{l}\text { I offer suggestions to my supervisor to improve the } \\
\text { workplace. }\end{array}$ & 0.783 & - & & \\
\hline $\begin{array}{l}\text { I explain problems to my supervisor and encourage } \\
\text { him or her to solve them. }\end{array}$ & 0.767 & 15.282 & & \\
\hline $\begin{array}{l}\text { Even if my opinions regarding work differ from those } \\
\text { of my supervisor, I still try to communicate with him } \\
\text { or her. }\end{array}$ & 0.755 & 14.996 & & \\
\hline $\begin{array}{l}\text { I always pay attention to workplace problems so that } \\
\text { my opinions are useful to the team. }\end{array}$ & 0.764 & 15.220 & & \\
\hline $\begin{array}{l}\text { I think about solutions to problems that affect my } \\
\text { team's quality of work and life. }\end{array}$ & 0.816 & 16.471 & & \\
\hline $\begin{array}{l}\text { I voice my opinions regarding new projects and } \\
\text { changes to my team. }\end{array}$ & 0.766 & 15.257 & & \\
\hline
\end{tabular}

A low correlation coefficient between two constructs suggests good discriminant validity $[42,43]$. The square root of the AVE of each dimension must be greater than the correlation coefficient between a given dimension and the other dimensions [37]. The discriminant validity analysis revealed that the square root of the AVE of each dimension ranges from 0.75 to 0.84 (Table 2), which is greater than the correlation coefficient between dimensions. Thus, the scales have favorable discriminant validity.

Table 2. Mean, standard error, square root of AVE, and correlation coefficients.

\begin{tabular}{|c|c|c|c|c|c|c|c|}
\hline Variables & Mean & SE & A & B & $\mathrm{C}$ & D & E \\
\hline A. Moral leadership & 3.80 & 0.64 & $\begin{array}{l}\mathbf{0 . 8 4} \\
1.00\end{array}$ & & & & \\
\hline B. Benevolent leadership & 3.41 & 0.76 & 0.53 & $\begin{array}{l}\mathbf{0 . 8 1} \\
1.00\end{array}$ & & & \\
\hline C. Authoritarian leadership & 3.17 & 0.76 & 0.05 & 0.19 & $\begin{array}{l}\mathbf{0 . 7 5} \\
1.00\end{array}$ & & \\
\hline D. Organizational identification & 3.84 & 0.57 & 0.18 & 0.36 & 0.30 & $\begin{array}{l}\mathbf{0 . 8 1} \\
1.00\end{array}$ & \\
\hline E. Voice behavior & 3.68 & 0.60 & 0.12 & 0.31 & 0.11 & 0.52 & $\begin{array}{l}\mathbf{0 . 7 7} \\
1.00\end{array}$ \\
\hline
\end{tabular}




\subsection{Hypothesis Testing}

Hypothesis 1-3 concerns the relationship between supervisors' paternalistic leadership (moral leadership, benevolent leadership, and authoritarian leadership) and hotel employees' voice behavior. To verify the hypotheses, this study uses voice behavior as the dependent variable; gender, age, and tenure as control variables; moral leadership, benevolent leadership, and authoritarian leadership as independent variables; and organizational identity as the moderating variable. The interaction terms of paternalistic leadership (moral, benevolent, and authoritarian leadership) and organizational identification are added to the regression formula. The results are listed in Table 3. The results indicate that moral leadership has a significant effect on voice behavior $(\beta=-0.11, p<0.05)$. Therefore, Hypothesis 1 is supported. Benevolent leadership has a significant effect on voice behavior $(\beta=0.21$, $p<0.001)$. Therefore, Hypothesis 2 is supported. Authoritarian leadership has a significant effect on voice behavior $(\beta=-0.11, p<0.05)$. Therefore, Hypothesis 3 is supported.

Table 3. Regression of paternalistic leadership and organizational identification for voice behavior.

\begin{tabular}{|c|c|}
\hline \multirow[b]{2}{*}{ Dependent Variable } & \multirow{2}{*}{ Voice Behavior } \\
\hline & \\
\hline Gender & $-0.08+$ \\
\hline Age & -0.05 \\
\hline Tenure & 0.07 \\
\hline Moral leadership & $-0.11 *$ \\
\hline Benevolent leadership & $0.21^{* * *}$ \\
\hline Authoritarian leadership & $-0.11 *$ \\
\hline Organizational identification & $0.45^{* * *}$ \\
\hline Moral leadership $\times$ Organizational identification & $-0.20^{* * *}$ \\
\hline Benevolent leadership $\times$ Organizational identification & $0.09+$ \\
\hline Authoritarian leadership $\times$ Organizational identification & $-0.09+$ \\
\hline $\mathrm{R}^{2}$ & 0.33 \\
\hline Adjusted $\mathrm{R}^{2}$ & 0.31 \\
\hline $\mathrm{F}$ & $17.09 * * *$ \\
\hline
\end{tabular}

Hypotheses 4-6 concerns whether organizational identification moderate the relationship between supervisors' paternalistic leadership (moral leadership, benevolent leadership, and authoritarian leadership) and hotel employees' voice behavior. The analysis results indicate that the interaction of moral leadership and organizational identification has a significant effect on voice behavior $(\beta=-0.20, p<0.001)$. Under a high degree of organizational identification, moral leadership negatively affects voice behavior (Figure 2a). Under a low degree of organizational identification, moral leadership positively affects voice behavior. Therefore, Hypothesis 4 is supported. The interaction between benevolent leadership and organizational identification has a significant effect on voice behavior $(\beta=0.09, p<0.10)$. Under a high degree of organizational identification, benevolent leadership positively affects voice behavior (Figure $2 b$ ). Under a low degree of organizational identification, benevolent leadership does not strongly affect voice behavior. Therefore, Hypothesis 5 is supported. The interaction between authoritarian leadership and organizational identification has a significant effect on voice behavior $(\beta=-0.09, p<0.10)$. Under a high degree of organizational identification, authoritarian leadership negatively affects voice behavior (Figure 2c). Under a low degree of organizational identification, authoritarian leadership does not strongly affect voice behavior. Therefore, Hypothesis 6 is supported. 
(a) Moderating effect of organizational identification on the relationship between moral leadership and voice behavior

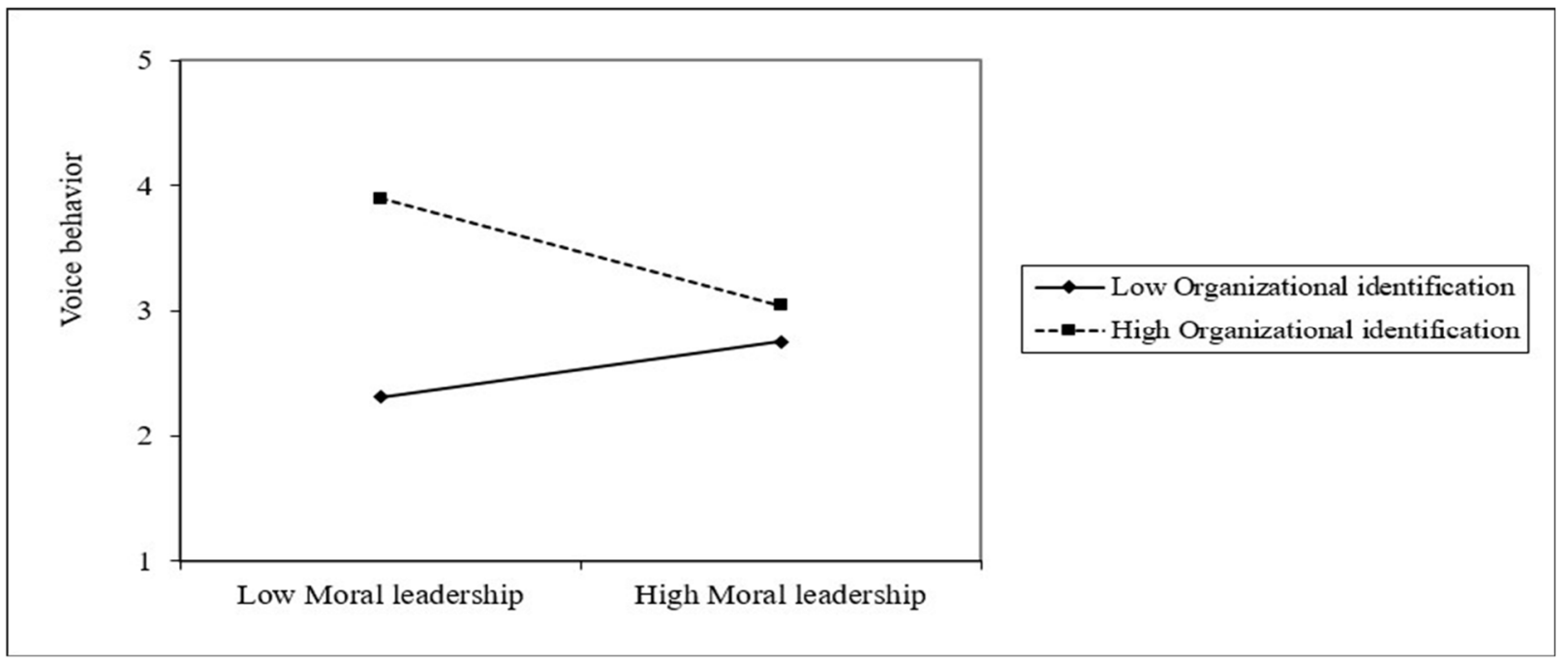

(b) Moderating effect of organizational identification on the relationship between benevolent leadership and voice behavior

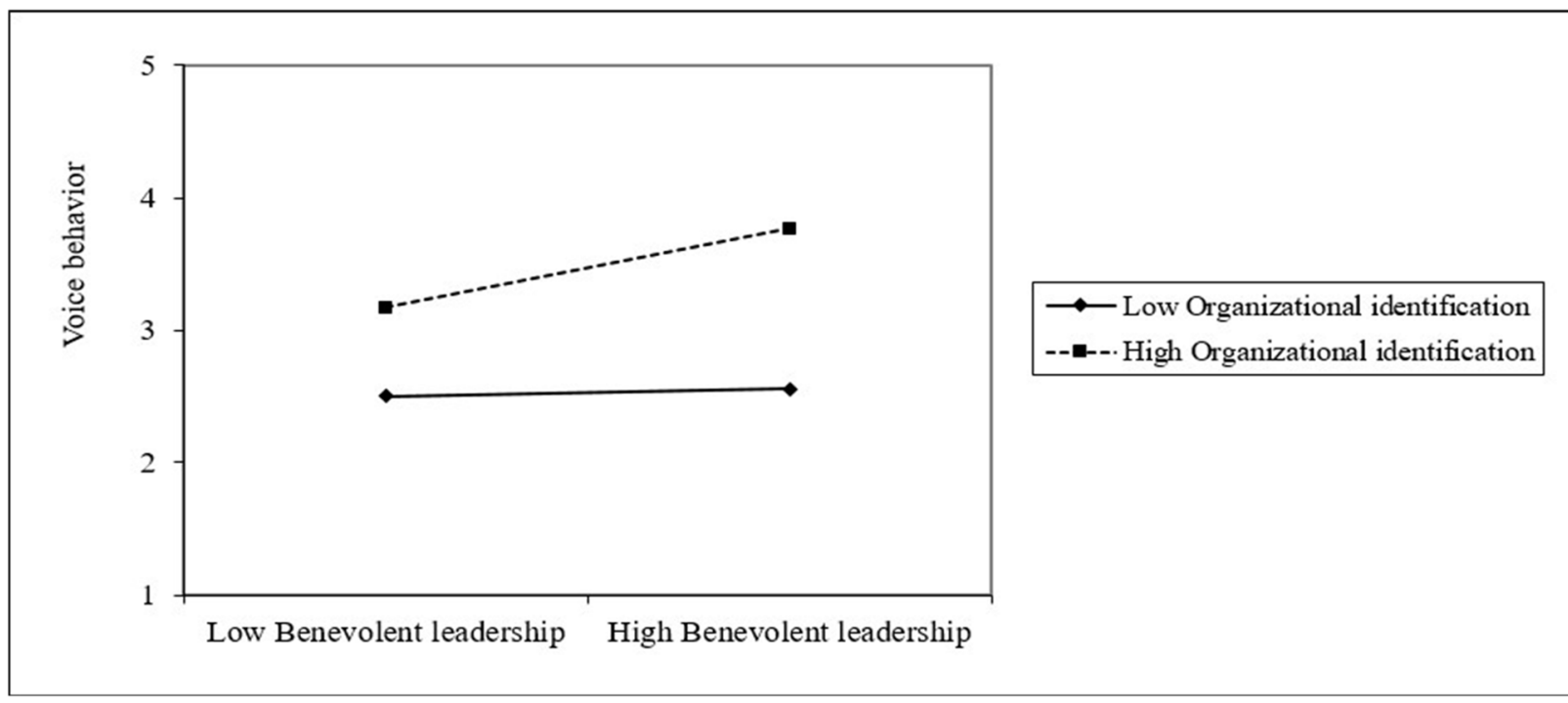

(c) Moderating effect of organizational identification on the relationship between authoritarian leadership and voice behavior

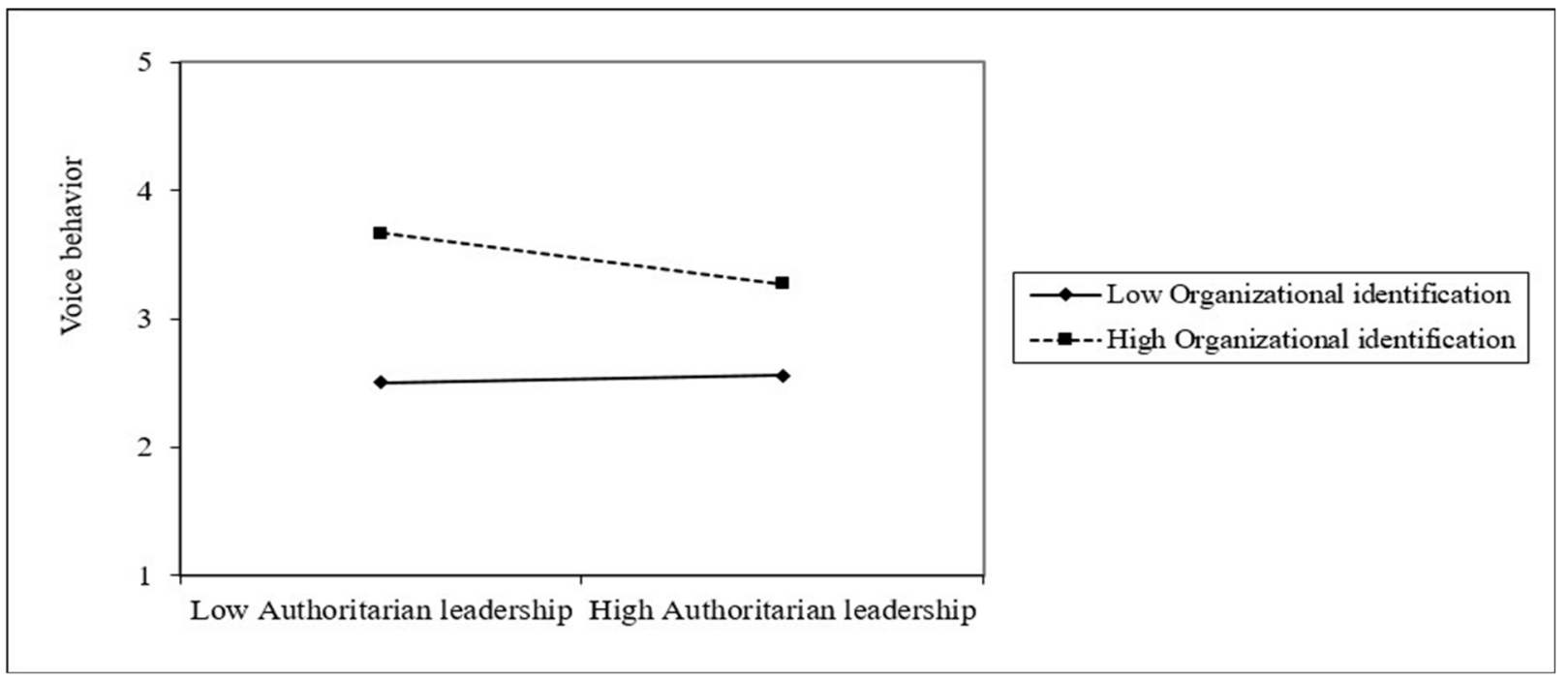

Figure 2. Moderating effect of organizational identification on the relationship between paternalistic leadership and voice behavior. 


\section{Discussion}

\subsection{Theoretical Implications}

There are many different potential advanced methods that can be used in behavioral science research, such as multi-objective particle swarm optimization [44], mixed logit model [45], hybrid choice modeling [46], Hayes' Process macro [47] and structural equation modeling [48]. This study uses multiple regression to test the research hypotheses. All six hypotheses are empirically supported. The analysis results indicate that supervisors' moral and authoritarian leadership discourages voice behavior among hotel employees and that benevolent leadership encourages voice behavior among hotel employees. This result is consistent with the viewpoint of social information processing theory. Organizational identification moderates the relationship between paternalistic leadership (moral leadership, benevolent leadership, and authoritarian leadership) and voice behavior; this result is consistent with the viewpoint of social identity theory. The analysis results confirm the findings of Dedahanov et al. [23] that supervisors' authoritarian leadership can decrease employees' voice behavior. On the other hand, the findings of this study extend the research of $\mathrm{Lu}$ and $\mathrm{Lu}$ [1], Dai et al. [18], Svendsen and Joensson [21], Ruiz-Palomino et al. [22], Han and Hwang [24], Shih and Wijaya [25], Liang et al. [26], Park et al. [27], and Cumberland et al. [28]. Different from the studies mentioned above that discuss the effects of person-organization fit, regulatory foci, commitment to change, encouragement to participate, psychological capital, team-member exchange, transformational leadership, supervisor empowerment, and work engagement on voice behavior, this study explores the effects of paternalistic leadership (moral leadership, benevolent leadership, and authoritarian leadership) and organizational identification on employees' voice behavior from the perspective of social information processing theory and social identity theory to fill a gap in the hospitality and tourism literature.

\subsection{Implications for Managerial Practice}

The results support Hypothesis 1, that is, supervisors' moral leadership discourages hotel employees from offering suggestions. Hypothesis 2 was also supported, indicating that supervisors' benevolent leadership encourages voice behavior among hotel employees. Hypothesis 3 was supported and indicates that supervisors' authoritarian leadership discourages hotel employees from offering suggestions. If hotel managers understand supervisors' leadership styles, they can instruct supervisors to use a benevolent leadership style and to listen to the opinions of their employees when necessary. To ensure employees follow the rules without voicing their opinions, hotel managers should instruct supervisors to lead by example and to care for their subordinates.

Hypotheses 4-6 were supported, indicating that if employees feel a sense of belonging in their hotels, moral and authoritarian leadership from supervisors can discourage voice behavior among employees, whereas benevolent leadership from supervisors encourages employees to voice their opinions. Employees with a high degree of organizational identification are more willing to express their opinions. Therefore, hotel managers can improve the workplace by considering salary, welfare, and other aspects from the perspective of their employees. This ensures that employees feel pride in their company, follow the company's rules, and display voice behavior when required.

\subsection{Limitations and Future Research}

Several limitations should be considered when interpreting the findings of this study and their implications; these limitations may also serve as a starting point for subsequent studies. First, the participants were employees in Taiwan's hotel industry. Whether the results can be extrapolated to other cultural contexts (such as Europe) should be investigated. Jin et al. [49] indicated that abusive behavior from supervisors can cause deviant behavior in the workplace. Abusive behavior from supervisors may affect the voice behavior of employees; this can be explored in subsequent studies. Dyne et al. [50] subdivided voice behavior into acquiescent voice, defensive voice, and prosocial voice behavior. Subse- 
quent studies can explore the effects of the three dimensions of paternalistic leadership on these three types of voice behavior. Furthermore, previous studies pointed out that shared leadership positively influences proactive behavior, creativity, and innovative behavior [51-53]. Future studies can explore the effects of shared leadership on hotel employees' voice behavior. Finally, prospect theory is regarded as a leading behavioral paradigm to understand decision making under risk and has been widely applied in psychological and behavioral economic studies $[54,55]$. Future research can use prospect theory to explore the antecedents of hotel employees' voice behavior.

Author Contributions: Conceptualization, W.-L.Z., C.-H.L. and C.-L.M.; methodology, W.-L.Z.; software, W.-L.Z.; validation, W.-L.Z., C.-H.L. and C.-L.M.; formal analysis, W.-L.Z.; investigation, W.-L.Z.; resources, C.-H.L. and C.-L.M.; data curation, W.-L.Z.; writing-original draft preparation, W.-L.Z., C.-H.L. and C.-L.M.; writing-review and editing, W.-L.Z., C.-H.L. and C.-L.M.; visualization, W.-L.Z.; supervision, W.-L.Z.; project administration, W.-L.Z.; funding acquisition, C.-H.L. and C.-L.M. All authors have read and agreed to the published version of the manuscript.

Funding: This research received no external funding.

Institutional Review Board Statement: Ethical review and approval were waived for this study due to the questionnaire survey for the article is an unnamed, non-interactive and non-intrusive research conducted in public, and will not identify specific individuals from the collected information.

Informed Consent Statement: Informed consent was obtained from all subjects involved in the study.

Data Availability Statement: Not applicable.

Conflicts of Interest: The authors declare no conflict of interest.

\section{References}

1. Lu, A.C.C.; Lu, L. Drivers of hotel employee's voice behavior: A moderated mediation model. Int. J. Hosp. Manag. 2020, 85, 102340.

2. Chen, M.; Lyu, Y.; Li, Y.; Zhou, X.; Li, W. The impact of high-commitment HR practices on hotel employees' proactive customer service performance. Cornell Hosp. Q. 2017, 58, 94-107. [CrossRef]

3. Loi, R.; Ao, O.K.; Xu, A.J. Perceived organizational support and coworker support as antecedents of foreign workers' voice and psychological stress. Int. J. Hosp. Manag. 2014, 36, 23-30. [CrossRef]

4. Dai, Y.D.; Chen, K.Y.; Zhuang, W.L. Moderating effect of work-family conflict on the relationship between leader-member exchange and relative deprivation: Links to behavioral outcomes. Tour. Manag. 2016, 54, 369-382. [CrossRef]

5. Dai, Y.D.; Hou, Y.H.; Chen, K.Y.; Zhuang, W.L. To help or not to help: Antecedents of hotel employees' organizational citizenship behavior. Int. J. Contemp. Hosp. Manag. 2018, 30, 1293-1313. [CrossRef]

6. Karatepe, O.M.; Beirami, E.; Bouzari, M.; Safavi, H.P. Does work engagement mediate the effects of challenge stressors on job outcomes? Evidence from the hotel industry. Int. J. Hosp. Manag. 2014, 36, 14-22. [CrossRef]

7. Kilic, H.; Okumus, F. Factors influencing productivity in small island hotels: Evidence from Northern Cyprus. Int. J. Contemp. Hosp. Manag. 2005, 17, 315-331. [CrossRef]

8. Raub, S. Does bureaucracy kill individual initiative? The impact of structure on organizational citizenship behavior in the hospitality industry. Int. J. Hosp. Manag. 2008, 27, 179-186. [CrossRef]

9. Redmond, J.; Sharafizad, J. Discretionary effort of regional hospitality small business employees: Impact of non-monetary work factors. Int. J. Hosp. Manag. 2020, 86, 102452. [CrossRef]

10. Tuan, L.T. Driving employees to serve customers beyond their roles in the Vietnamese hospitality industry: The roles of paternalistic leadership and discretionary HR practices. Tour. Manag. 2018, 69, 132-144. [CrossRef]

11. Chen, W.J. Factors influencing internal service quality at international tourist hotels. Int. J. Hosp. Manag. 2013, 35, 152-160. [CrossRef]

12. Ashforth, B.E.; Mael, F. Social identity theory and the organization. Acad. Manag. Rev. 1989, 14, 20-39. [CrossRef]

13. Hogg, M.A.; Terry, D.J. Social identity and self-categorization processes in organizational contexts. Acad. Manag. Rev. 2000, 25, 121-140. [CrossRef]

14. Van Dyne, L.; Cummings, L.L.; Parks, J.M. Extra-role behaviors: In pursuit of construct and definitional clarity. Res. Organ. Behav. 1995, 17, 215-285.

15. LePine, J.A.; Van Dyne, L. Predicting voice behavior in work groups. J. Appl. Psychol. 1998, 83, 853-868. [CrossRef]

16. Morrison, E. Employee voice behavior: Integration and directions for future research. Acad. Manag. Ann. 2011, 5, 373-412. [CrossRef] 
17. Bashshur, M.R.; Oc, B. When voice matters a multilevel review of the impact of voice in organizations. J. Manag. 2015, 41, 1530-1554.

18. Dai, Y.D.; Zhuang, W.L.; Yang, P.K.; Wang, Y.J.; Huan, T.C. Exploring hotel employees' regulatory foci and voice behavior: The moderating role of leader-member exchange. Int. J. Contemp. Hosp. Manag. 2021, 33, 27-47. [CrossRef]

19. McClean, E.J.; Burris, E.R.; Detert, J.R. When does voice to exit? It depends on leadership. Acad. Manag. J. 2013, 56, 525-548. [CrossRef]

20. Morrison, E.W.; Wheeler-Smith, S.; Kamdar, D. Speaking up in groups: A cross-level study of group voice climate. J. Appl. Psychol. 2011, 96, 183-191. [CrossRef]

21. Svendsen, M.; Joensson, T.S. Transformational leadership and change related voice behavior. Leadersh. Organ. Dev. J. 2016, 37, 357-368. [CrossRef]

22. Ruiz-Palomino, P.; Hernández-Perlines, F.; Jiménez-Estévez, P.; Gutiérrez-Broncano, S. CEO servant leadership and firm innovativeness in hotels: A multiple mediation model of encouragement of participation and employees' voice. Int. J. Contemp. Hosp. Manag. 2019, 31, 1647-1665. [CrossRef]

23. Dedahanov, A.T.; Lee, D.H.; Rhee, J.; Yoon, J. Entrepreneur's paternalistic leadership style and creativity: The mediating role of employee voice. Manag. Decis. 2016, 54, 2310-2324. [CrossRef]

24. Han, M.C.; Hwang, P.C. How leader secure-base support facilitates hotel employees' promotive and prohibitive voices: Moderating role of regulatory foci. Int. J. Contemp. Hosp. Manag. 2019, 31, 1666-1683. [CrossRef]

25. Shih, H.A.; Wijaya, N.H.S. Team-member exchange, voice behavior, and creative work involvement. Int. J. Manpow. 2017, 38, 417-431. [CrossRef]

26. Liang, T.L.; Chang, H.F.; Ko, M.H.; Lin, C.W. Transformational leadership and employee voices in the hospitality industry. Int. J. Contemp. Hosp. Manag. 2017, 29, 374-392. [CrossRef]

27. Park, I.J.; Doan, T.; Zhu, D.; Kim, P.B. How do empowered employees engage in voice behaviors? A moderated mediation model based on work-related flow and supervisors' emotional expression spin. Int. J. Hosp. Manag. 2021, 95, 102878. [CrossRef]

28. Cumberland, D.M.; Shuck, B.; Immekus, J.; Alagaraja, M. An emergent understanding of influences on managers' voices in SMEs. Leadersh. Organ. Dev. J. 2018, 39, 234-247. [CrossRef]

29. Farh, J.L.; Cheng, B.S. A cultural analysis of paternalistic leadership in Chinese organizations. In Management and Organization in the Chinese Context; Li, J.T., Tsui, A.S., Weldon, E., Eds.; Macmillan: London, UK, 2000; pp. 85-127.

30. Cheng, B.S.; Chou, L.F.; Wu, T.Y.; Huang, M.P.; Farh, J.L. Paternalistic leadership and subordinate responses: Establishing a leadership model in Chinese organizations. Asian J. Soc. Psychol. 2004, 7, 89-117. [CrossRef]

31. Mussolino, D.; Calabrò, A. Paternalistic leadership in family firms: Types and implications for intergenerational succession. J. Fam. Bus. Strategy 2014, 5, 197-210. [CrossRef]

32. Pellegrini, E.K.; Scandura, T.A. Paternalistic leadership: A review and agenda for future research. J. Manag. 2008, 34, 566-593. [CrossRef]

33. Salancik, G.R.; Pfeffer, J. A social information processing approach to job attitudes and task design. Adm. Sci. Q. 1978, 23, 224-253. [CrossRef]

34. Tajfel, H. Differentiation between Social Groups: Studies in the Social Psychology of Intergroup Relations; Academic Press: London, UK, 1978.

35. Ashforth, B.E.; Harrison, S.H.; Corley, K.G. Identification in organizations: An examination of four fundamental questions. J. Manag. 2008, 34, 325-374. [CrossRef]

36. Teng, C.; Lu, A.; Huang, Z.; Fang, C. Ethical work climate, organizational identification, leader-member-exchange (LMX) and organizational citizenship behavior (OCB): A study of three star hotels in Taiwan. Int. J. Contemp. Hosp. Manag. 2020, 32, 212-229. [CrossRef]

37. Hair, J.F.; Anderson, R.E.; Tatham, R.L.; Black, W.C. Multivariate Data Analysis, 5th ed.; Prentice Hall: Upper Saddle River, NJ USA, 1998.

38. Cheng, B.S.; Chou, L.F.; Huang, M.P.; Farh, J.L.; Peng, S.Q. A triad model of paternalistic leadership: Evidence from business organizations in Mainland China. Indig. Psychol. Res. Chin. Soc. 2003, 20, 209-250.

39. Mael, F.A.; Ashforth, B.E. Alumni and their alma mater: A partial test of the reformulated model of organizational identification. J. Organ. Behav. 1992, 13, 103-123. [CrossRef]

40. Van Dyne, L.; LePine, J.A. Helping and voice extra-role behaviors: Evidence of construct and predictive validity. Acad. Manag. J. 1998, 14, 108-119.

41. Bagozzi, R.P.; Yi, Y.J. On the evaluation of structural equation model. J. Acad. Mark. Sci. 1988, 16, 74-94. [CrossRef]

42. Fornell, C.; Larcker, D.F. Evaluating structural equation models with unobservable variables and measurement error. J. Mark. Res. 1981, 18, 39-50. [CrossRef]

43. Anderson, J.C.; Gerbing, D.W. Structural equation modeling in practice: A review and recommended two-step approach. Psychol. Bull. 1988, 103, 411-423. [CrossRef]

44. Liu, J.; Dai, Q. Portfolio optimization of photovoltaic/battery energy storage/electric vehicle charging stations with sustainability perspective based on cumulative prospect theory and MOPSO. Sustainability 2020, 12, 985. [CrossRef]

45. González, R.M.; Marrero, Á.S.; Cherchi, E. Testing for inertia effect when a new tram is implemented. Transp. Res. Part A Policy Pract. 2017, 98, 150-159. [CrossRef] 
46. Gao, K.; Yang, Y.; Sun, L.; Ou, X. Revealing psychological inertia in mode shift behavior and its quantitative influences on commuting trips. Transp. Res. Part F Traffic Psychol. Behav. 2020, 71, 272-287. [CrossRef]

47. Oh, K.-S.; Han, J.R.; Park, S.R. The influence of hotel employees' perception of CSR on organizational commitment: The moderating role of job level. Sustainability 2021, 13, 12625. [CrossRef]

48. Kim, M.J.; Hall, C.M.; Bonn, M. Factors affecting pandemic biosecurity behaviors of international travelers: Moderating roles of gender, age, and travel frequency. Sustainability 2021, 13, 12332. [CrossRef]

49. Jin, D.; Kim, K.; DiPietro, R.B. Workplace incivility in restaurants: Who's the real victim? Employee deviance and customer reciprocity. Int. J. Hosp. Manag. 2020, 86, 102459. [CrossRef]

50. Dyne, L.V.; Ang, S.; Botero, I.C. Conceptualizing employee silence and employee voice as multidimensional constructs. J. Manag. Stud. 2003, 40, 1359-1392. [CrossRef]

51. Fu, H.; Ye, B.H.; Xu, X. The cross-level effect of shared leadership on tourism employee proactive behavior and adaptive performance. Sustainability 2020, 12, 6173. [CrossRef]

52. Wu, C.M.; Chen, T.J. Collective psychological capital: Linking shared leadership, organizational commitment, and creativity. Int. J. Hosp. Manag. 2018, 74, 75-78. [CrossRef]

53. Vandavasi, R.K.K.; McConville, D.C.; Uen, J.-F.; Yepuru, P. Knowledge sharing, shared leadership and innovative behaviour: A cross-level analysis. Int. J. Manpow. 2020, 41, 1221-1233. [CrossRef]

54. Li, Z.; Hensher, D. Prospect theoretic contributions in understanding traveller behaviour: A review and some comments. Transp. Rev. 2011, 31, 97-115. [CrossRef]

55. Gao, K.; Sun, L.; Yang, Y.; Meng, F.; Ou, X. Cumulative prospect theory coupled with multi-attribute decision making for modeling travel behavior. Transp. Res. Part A Policy Pract. 2021, 148, 1-21. [CrossRef] 